\title{
Isquemia Miocárdica Silenciosa e Aspectos da Ventilação em Pacientes com Obesidade Mórbida, dois Assuntos de Interesse Atual
}

D ois artigos científicos, estudando aspectos da anestesia nestes grupos de pacientes estão neste número.

A relação da isquemia miocárdica silenciosa com a técnica de anestesia para cirurgia não cardíaca em pacientes de risco e possíveis marcadores com poder de predição são assuntos de relevância na prática diária. No estudo apresentado neste número da Revista, duas técnicas de anestesia no neuro-eixo, peridural e raquianestesia, não demonstraram diferença sobre a incidência de isquemia miocárdica silenciosa em pacientes submetidos à ressecção endoscópica de próstata, avaliada por monitorização com Holter 24 horas após a intervenção cirúrgica. Resultado diverso foi encontrado em estudo que monitorizou pacientes submetidos à cirurgia do andar superior do abdômen com anestesia geral, associada ou não à peridural, e analgesia sistêmica ou peridural no pós-operatório. No grupo com peridural associada à anestesia geral, tanto no período cirúrgico como no pós-operatório a incidência de isquemia miocárdica silenciosa foi até 4 vezes menor nas primeiras 24 horas ${ }^{1}$.

O emprego de métodos invasivos para o diagnóstico pode ser indicado quando pacientes de risco são programados para cirurgias vasculares ou em pacientes com mais de um fator clínico de risco. Os portadores de diabete melito por apresentarem alta prevalência de isquemia miocárdica silenciosa, necessitam cuidado especial ${ }^{2}$.

Laito e col. em 2004 observaram que a variabilidade na freqüência cardíaca pré-operatória, avaliada por Holter em pacientes idosos aguardando tratamento cirúrgico de fratura de quadril, foi prognóstica para isquemia miocárdica silenciosa prolongada ( maior que 10 minutos) ${ }^{3}$.

A isquemia miocárdica silenciosa é uma entidade clínica relativamente comum, mas incompletamente esclarecida. As evidências sugerem que pacientes com alto risco para isquemia miocárdica, mesmo na ausência de sintomas, beneficiam-se de investigação diagnóstica precisa, eventualmente invasiva e tratamento imediato ${ }^{4}$.

A repercussão da obesidade mórbida sobre a mecânica respiratória foi observada em diversos trabalhos. Os principais meios para diminuir essa indesejável alteração foram estudados durante cirurgia bariátrica e no tratamento cirúrgico de outras afecções que podem acometer este grupo de pacientes. O efeito da variação do volume corrente, freqüência respiratória, PEEP, posição de cefaloaclive, pneumoperitôneo, da abertura da parede abdominal foram analisados ${ }^{5-7}$. Em estudo apresentado neste número da Revista, a ventilação foi realizada com Volume Corrente de oito $\mathrm{ml}$ por quilo de peso ideal e monitorizada por $\mathrm{SpO}_{2}$ e $\mathrm{P}_{\mathrm{ET}} \mathrm{CO}_{2}$ com valores pré-determinados, sem o emprego de PEEP durante gastroplastia. Ajustes no volume corrente e/ou freqüência respiratória guiados pela $\mathrm{P}_{\mathrm{ET}} \mathrm{CO}_{2}$ e $\mathrm{SpO}_{2}$ proporcionaram resultado adequado. Sprung e col. ${ }^{6}$ não observaram os mesmos resul- tados em estudo comparativo entre dois esquemas de ventilação em obesos mórbidos. O impacto do uso de PEEP e da posição de cefaloaclive no débito cardíaco, avaliado por Perilli e col. ${ }^{8}$, contrapõe-se parcialmente ao benefício destas estratégias em relação à ventilação.

Apesar da demonstração de que o volume corrente calculado em relação ao peso ideal do paciente é eficiente, a discussão sobre o uso e valor do PEEP ideal permanece.

Dra. Judymara Lauzi Gozzani, TSA

Editor-Chefe da Revista Brasileira de Anestesiologia

\section{Silent Myocardial Ischemia and Ventilation in the Morbidity Obese Patient, Currently Interesting Subjects}

Two scientific articles studying aspects of anesthesia in these groups of patients are published in this edition.

The relationship between silent myocardial ischemia and anesthetic technique for non-cardiac surgeries in patients at risk and potential predictive markers are relevant issues in our daily practice.

In a study published in this edition, two neuraxial anesthetic techniques - epidural and spinal - have not shown differences in the incidence of silent myocardial ischemia in patients submitted to endoscopic prostate resection, evaluated by Holter 24 hours after surgery. A different result was found in a study monitoring patients submitted to upper abdominal surgeries under general anesthesia, associated or not to epidural anesthesia and postoperative systemic or epidural analgesia. In the group receiving epidural associated to general anesthesia, the incidence of silent myocardial ischemia, both in the intra and postoperative period, has been up to 4 times lower in the first 24 hours ${ }^{1}$.

Invasive diagnostic methods may be indicated for risk patients scheduled for vascular surgeries or for patients with more than one clinical risk factor. Special care is needed for diabetes mellitus patients due to their high prevalence of silent myocardial ischemia ${ }^{2}$.

Laito et al., in 2004, have observed that variations in preoperative heart rate evaluated by Holter in elderly patients awaiting for surgical fractured hip surgery were prognostic for prolonged silent myocardial ischemia (longer than 10 minutes) ${ }^{3}$. Silent myocardial ischemia is a relatively common clinical event, yet not totally explained. Evidences suggest that patients at high risk for myocardial ischemia, even in the absence of symptoms, benefit from accurate diagnostic, eventually invasive, investigation and prompt treatment ${ }^{4}$. 
The impact of morbid obesity on respiratory mechanics has been observed in several studies. Primary means to decrease this undesirable change were studied during bariatric surgery and surgical treatment of other problems which may affect this group of patients. The effects of changes in tidal volume, respiratory rate, PEEP, head up position, pneumoperitoneum and abdominal wall opening were evaluated ${ }^{5-7}$.

In a study published in this edition, ventilation was performed with tidal volume of $8 \mathrm{ml}$ per $\mathrm{kg}$ of ideal weight and monitored by $\mathrm{SpO}_{2}$ and $\mathrm{P}_{\mathrm{ET}} \mathrm{CO}_{2}$ with predetermined values, without PEEP during gastroplasty. Tidal volume and/or respiratory rate adjustments guided by $\mathrm{P}_{\mathrm{ET}} \mathrm{CO}_{2}$ and $\mathrm{SpO}_{2}$ have provided adequate results.

Sprung et al. ${ }^{6}$ have not observed the same results in a comparative study between two ventilation regimens for morbidly obese patients. The impact of PEEP and head up position on cardiac output, evaluated by Perilli et al. ${ }^{8}$, is partially opposed to the benefit of these ventilation strategies.

Notwithstanding the demonstration that tidal volume calculated as a function of patient's ideal weight is efficient, the discussion about PEEP use and ideal value still remains.

Judymara Lauzi Gozzani, TSA. M.D.

Editor in Chief, Brazilian Journal of Anesthesiology

\section{REFERÊNCIAS - REFERENCES}

01. Limberi S, Markou N, Sakayianni Ket al - Coronary artery disease and upper abdominal surgery: impact of anesthesia on perioperative myocardial ischemia. Hepatogastroenterology, 2003;50:1814-1820.

02. Sprynger M - Evaluation, severity and prognostic significance of silent myocardial ischaemia in vascular patients. Acta Chir Belg, 2003;103:255-261.

03. Laitio TT, Huikuri HV, Makikallio TH et al - The breakdown of fractal heart rate dynamics predicts prolonged postoperative myocardial ischemia. Anesth Analg, 2004;98: 1239-1244.

04. Almeda FQ, Kason TT, Nathan S et al - Silent myocardial ischemia: concepts and controversies. Am J Med, 2004;116: 112-118.

05. Sprung J, Whalley DG, Falcone T et al - The impact of morbid obesity, pneumoperitoneum, and posture on respiratory system mechanics and oxygenation during laparoscopy. Anesth Analg, 2002;94:1345-1350.

06. Sprung J, Whalley DG, Falcone T et al - The effects of tidal volume and respiratory rate on oxygenation and respiratory mechanics during laparoscopy in morbidly obese patients. Anesth Analg, 2003;97:268-274

07. Auler Jr JOC, Miyoshi E, Fernandes CR et al - The effects of abdominal opening on respiratory mechanics during general anesthesia in normal and morbidly obese patients: a comparative study. Anesth Analg, 2002;94:741-748.

08. Perilli V, Sollazzi L, Modesti C et al - Comparison of positive end-expiratory pressure with reverse Trendelenburg position in morbidly obese patients undergoing bariatric surgery: effects on hemodynamics and pulmonary gas exchange. Obes Surg, 2003;13:605-609. 